\title{
The Domestication and Arabization of the Bard: Towards the Reception of Shakespeare in the Arab World
}

\begin{abstract}
Since Najib al-Haddad and Tanyus“ Abdu's first Arabic versions of Romeo and Juliet and Hamlet at the end of the $19^{\text {th }}$ century, the reception of Shakespeare in the Arab world has gone through a process of adaptation, Arabization, and translation proper. We consider the process of Arabization / domestication of Shakespeare's plays since Najib al-Haddad's adaptation of Romeo and Juliet and Tanyus' Abdu's adaptation of Hamlet, to the achievements of Khalīl Mutran and Muhammad Hamdi. We underline, as particular examples of Shakespeare's appropriation, the literary response of Ali Ahmed Bakathir, Muhammad al-Maghut and Mamduh Udwan, with a particular stress on Khazal al-Majidi and his adaptations of Shakespeare's plays. All these writers reposition Shakespeare's plays in an entirely different cultural space.
\end{abstract}

Keywords: adaptation, Arabic, Arabization, cultural transfer, Khazal al-Majidi, repositioning, Shakespeare, translation

\section{Introduction: Arabization as a framework}

Spencer Dan Scoville, in his PhD dissertation, The Agency of the Translator: Khalil Baydas' Literary Translations (2012), quotes an excerpt from the letter sent in 1895 by a Palestinian student, Khalil Baydas, to the Egyptian journal al-Hilal:

If a person Arabicized ( 'arraba) a European novel, carrying across (naqala) its meanings into an eloquent and impeccable (fașịhah) Arabic idiom, which does not create the impression that it has been Arabicized ( ta $^{\prime} \mathrm{r} \overline{\mathrm{l}} \mathrm{b}$ ), and took liberties (tașarrafa) with the novel as he saw fit, but left the historical events and the proper nouns unchanged [...], if he read a European (ifranjiyyah) novel and adapted it, and wrote it down to the best of his linguistic abilities, using Arabic proverbs, spicing it up with verse, and using the idioms of the Arabs and their modes of expression, then what should his work be called-an Arabicization ( ta $\left.^{\prime} r \bar{\imath} b\right)$ ? A composition (tașīf)? Or what? (Scoville 4)

* University of Thi-Qar, Nassiriyah, Iraq. 
The letter is concerned with different issues of the translation of European literature, particularly the novel, into Arabic and stresses the importance of fidelity in literary translation. He uses two different Arabic words for "translation": naqala (naql) and 'arraba (ta'rìb), to which he assigns two different meanings: thus, the process of naql is linked to the meaning of the text, while 'arraba is linked to the complex process of bringing a literary text into the Arabic context. By its extra semantic value, 'arraba ("to Arabize") adds to the process the translator's adaptation and originality. By resorting to $t a$ ' $r \bar{\imath} b$, the translator goes beyond the surface meaning of the words in the source language text to its stylistic effects which he captures and renders in the new linguistic and social environment (target language).

In a study conducted by Gregor Meiering and Next Page Foundation in 2004, the authors have highlighted several aspects of the process of Arabization (ta'rib), a term which, though synonymous with translation (tarjama), "reflects a much broader concept and is indeed of wider implications for translating". Its purpose was the promotion of literary Arabic in all fields - education, science, administration and politics, leading to the development of a modern standard version of Arabic, to enhance "the transfer and growth of knowledge among speakers whose mother tongue is (colloquial) Arabic" (Idem). The aim of Arabization was to enhance "the efficiency of education, and strengthen the cultural self-consciousness in Arab societies" and "to create channels of opening up towards the outside world, allowing Arabic to become a language capable of expressing modern concepts and to develop itself into a language of knowledge production". As a conclusion, "Arabization must be seen as a huge linguistic challenge that was at times taken and at times missed by Arab political elites. Arabization as a grassroots project was traditionally seen as a vehicle of achieving democracy and promoting Arab unity" (Next Page 5).

Obviously, the technique of Arabization is the Arabic version of domestication which, together with foreignization represents the two strategies used by translators, especially those specialized in literary translation, and which have a specific application in the case of the literary translations from English into Arabic - two different languages representing different cultures. However, as is obvious, the two techniques are not limited to translating from English into Arabic and can be used with any language.

\section{The Arab view}

We are justified to believe that preservation of cultural essence in translating into Arabic any of Shakespeare's plays or poems is an extremely difficult task for the linguistic and cultural remoteness of the two involved languages, English and Arabic. Especially in literary texts, it should be considered that source and 
target language equivalents have to entertain similar spirits, regardless of the verbal violation of the source text, and rarely does literary translation attain the stability of the original work. The translator encounters great difficulties with what the target language may offer him/her of expressions that can hold similar spiritual or essential functions and convey features of beauty of which readers can be entertained and pleased. Commenting on the translation of Shakespeare's Sonnet 18, "Shall I compare thee to a summer's day", Bakri Al-Azzam points out that,

The description of beauty that Shakespeare gives in the sonnet does not apply in Arabia, for instance, where summer is the time of hot days, thirst, and dry and devastating winds. In this case, it is better to give the translator the license to introduce new notions that convey such features of beauty from Arabia, through the reading of which Arab readers and those who have good knowledge of Arabic can be entertained. In addition, along with the translated version, the translator should explain the beautiful features of the original work so that readers can understand both cultures by comparing the two texts. Shakespeare chooses summer as a beautiful. (Al-Azzam 64-65)

Though similar cultural expressions may not often stand for identical spirits or essences, replacing them by expressions that may carry identical connotations can be recommended, provided that the conveyed material is propped up with enough considerations of their implications. In other words, the translator has to "situationalize" the text by relating it to its environment, both verbal and non-verbal (Hatim 1990).

Finally, the translator should understand and live the mentality and thinking of the source text writer and audience, on the one hand, and that of the target text readers, on the other (Al-Azzam 62). The same point is put but differently by Haywood (ix) who, in his volume Modern Arabic Literature (1971) asserts that,

[in the translation of Arabic literature] there is something to be said for literal translation, which, though apt to be stilted, sometimes gives the flavour of the original. On the other hand, free translation can produce better literature and pleasanter reading. Poetry should not be translated as prose: this is a certain road to boring the reader. So, verse should be translated in verse, almost invariably with rhyme. (Haywood ix)

All along the process of translation, the new literary text in the target language is individually thought, and individually formed. Its creation is based upon the translator's experience and reaction towards certain events. In other words, the writer shows his intrinsic response and feedback in a transcribed manner, which very often differs from the manner of others, though sharing similar 
experiences. Not only this, but also the way the audience or reader comprehends the literary text differs from one person to another, which is also another literary translation complication. This requires that the translator should be deviant and extraneous to make cultural shifts in order to produce similar cultural influence on the reader of the target language (Dickins, Hervey and Higgins 32).

\section{Translators and translations}

In his essay, "Decomercializing Shakespeare: Mutran's translation of Othello" (2007), Sameh F. Hanna stresses the contribution of the Syro-Lebanese translators who emigrated to Egypt during the al-Nahda period and played a significant role "in initiating and promoting such new cultural activities as journalism, theatre and translation", focusing on drama and popular fiction. According to Hanna,

These cultural products were qualitatively different both from the elitist culture offered by scholars of religion ('ulama') — religious exegesis, books on Arabic grammar and rhetoric, commentaries on classical poetry and various books of tradition (turath) - and from the popular culture of the time, which mainly found expression in popular singing, folk tales, and acrobat and circus playing, all practised in such public spaces as markets and cafés. (Hanna 37)

Tanyus 'Abdu (1869-1926), himself a playwright, fiction writer and journalist, stands out as one of the outstanding translators of plays for the stage. According to Hanna, his translations illustrate "the practices of early Shakespeare translators and the translation norms to which they subscribed" (Hanna 29). One example is his 1901 version of Hamlet which responds to the requirements of the market the expectations of theatregoers at the time. He adapted the play so as make it more accessible to the audience: Hamlet does not die in the end of the play and retrieves his father's throne. Also, the leading role is performed by Shaykh Salama Hijazi a popular singer whose death on stage would not have been accepted by the Cairene audience. What is remarkable about 'Abdu's translation is that he translated from the French, appropriating and adapting the French version by Alexandre Dumas, père. In her seminal volume Hamlet's Arab Journey (2011), Margret Litvin points out that,

Abdu's debt to Dumas explains nearly all the peculiarities of his Hamlet, from the apparent padding throughout (the French alexandrine is two syllables longer than Shakespeare's iambic pentameter line) to the cleaned-up plot and added scenes. All the character changes with which Arab critics have reproached Abdu - the decisive Hamlet, the active Ophelia, the unsensual Gertrude, and the prayerless Claudius - can be traced to his peculiar French source. (Litvin 65) 
One peculiar feature of the translation activity at the beginning of the $20^{\text {th }}$ century is the increase of the number of published translations with the Egyptian elite as the target readership. Sameh F. Hanna comments upon the paratexts which the new translators resort to with the purpose of framing and packaging their work, such as the dedication of Muhammad 'Iffat's translation of Macbeth: "Our Arabization is dedicated to the whole world; to every writer, poet or scholar" (Hanna 33). It is the translator's way of asserting that,

Shakespeare is not for entertainment or pastime in theatres, but rather for study and meditation through reading, as Sami al-Juraydini says in the preface to his translation of Hamlet whose first edition was most probably published around the second decade of the twentieth century. (al-Juraydini 8)

The developments in theatre production in the 1910s triggered a significant change in the principles underlying the translation of drama supported by the rise of a new generation of translators supported by distinguished theatre critics such as Muhammad Taymur, who highly appreciated the translations of Khalil Mutran which counterbalanced the commercial versions of Tanyus 'Abdu.

Unlike his predecessors, Mutran and his peers were not financially dependent on published translations. They were educated, middle-class professionals with well-established positions in society. According to Hanna, these newcomers to the translation business made good use of their education and social position:

By flagging their cultural and educational assets and their social resources, especially on the covers of published translations, these new translators strove to challenge the authority of the old group whose legitimacy in the field was mainly dependent on the box office success of their translations. (Hanna 36)

It is interesting to note that over a span of one century there were fourteen different translations of Hamlet, eight translations of King Lear, ten translations of Macbeth, and eleven translations of Othello. Most of these translations were published in Egypt (Cairo and Alexandria), but also in Kuwait, Tunisia, Sudan, and Lebanon. Among the translators listed, the most prolific is Khalil Mutran, who translated four of Shakespeare's plays: Othello, Hamlet, Macbeth, and The Merchant of Venice. Apart from al-Haddad's translation of Romeo and Juliet, another translation of the same play was produced in 1898 by Tanyus 'Abdu (1869-1926), who also translated Hamlet for the stage in 1901. An anonymous translation of Othello published in 1910 is also allegedly authored by 'Abdu (Najm 243).

The translator took their time to properly advertise their work. Thus, Muhammad Hamdi, the translator of Julius Caesar (1912) introduces himself as "a teacher of translation at the Higher School of Teachers", while Muhammad 
'Iffa, the translator of The Tempest (1909) and Macbeth (1911) prefers more personal allusions when he describes himself as "an ex-judge in civil courts", and "the son of Khalil Pasha "Iffat". Perhaps following the example of Shakespeare himself who dedicated his sonnets to his patron, 'Iffat seeks for commercial success and does not hesitate to mention his personal connection to a prominent figure of the day when he confesses the support of Shaykh Muhammad "Abdu who "encouraged me to publish it" (the translation of The Tempest).

We should mention that all the representatives of this new generation of translators, and the translators of Shakespeare were no exception, placed a major emphasis on a printed statement on their fidelity to the original. It soon became a practice. For example, in 1912, prestigious translators as Khalīl Mutran (Othello), Muhammad Hamdi and Sami al-Juraydini (Julius Caesar) write in the prefaces to their translations that they are almost literal renderings of what Shakespeare says, "letter for letter, word for word", where "no word, phrase, simile, metonymy, nor metaphor is left out" (qtd by Hanna 37).

\section{Shakespeare, admirer of Arabs?}

From anecdotal and recorded evidence, the fact remains that one of the main reasons why Shakespeare is popular and respected by many Arabs is because they believe that in The Merchant of Venice he put Shylock and his race, the Jews, whom Arabs view as the orchestrators of Zionism, in the most unfavourable light. It is also the belief of many Arabs that when Shakespeare referred to Arabs and Arab elements on various occasions, he, in the main, spoke about them positively. For instance, in an article that appeared as early as 1956 in the Baghdad periodical, Ahl al-Naft, the Iraqi critic Safā' Khulūsi commented, "In The Merchant of Venice he [Shakespeare] presents the prince of Morocco as a noble and honourable man who is handsome and courteous, whilst he portrays the Jew Shylock with all connotations of villainy and baseness" (Khulūsi 14).

Khulūsi also echoes the commonly held view in the Arab world that in Othello Shakespeare is an "admirer of Arabs". According to Khulūsi, Shakespeare, apart from making Othello, an Arab like themselves, the titular hero of one of his major tragedies, he on the whole portrays Othello as valiant, devoted, and of noble nature:

He [Shakespeare] devotes one play to a Moorish Arab, Othello... We see Shakespeare as an admirer of the Arabs. He endows Othello with courage and manly qualities. He presents him [Othello] as a valiant man and jealous of his honour. When he becomes aware of his error, he does not hesitate to die the death of a Roman hero. (Khulūsi 13) 
Part of many Arabs' appreciation of Shakespeare lies in the fact that they think that Shakespeare's fascination with Arabic elements is manifest in the fact that he used a number of Arab locales to provide colourful scenes to two of his plays: a historical play, Antony and Cleopatra, and a romance, Pericles, Prince of Tyre. Part of the action of Antony and Cleopatra is set in Alexandria in Egypt and part of Pericles is set in Tyre in Lebanon and in Antioch (the historical Syrian city, now occupied by Turkey). Furthermore, the heroes of these two plays are of particular fascination to the Arabs: Cleopatra, whom many Arabs cannot accept as being any other than an Egyptian Queen, and Pericles, whom many Arabs speculate to be an Arab Prince or at least an Oriental one. Moreover, Tunis, though ostensibly not the immediate setting of The Tempest, some Arabs, nevertheless, appreciate the fact that it plays an important role in the background to the play. It is from Tunis that Alonso, King of Naples, Antonio, Duke of Milan, and other courtiers were returning from the wedding party of King Alonso's daughter to the King of Tunis, when their ship was overtaken in the opening scene by the terrible tempest raised by Prospero, the rightful Duke of Milan, with the help of his sprite, Ariel.

A few Arab critics, however, have adopted an entirely different trend of thinking as regards Shakespeare's attitudes not only to Arabs but to the Orient and Oriental subjects. Hawamdeh argues that Shakespeare, like many other Renaissance dramatists, if not necessarily expressing his own attitudes or judgment regarding Orientals and Muslims, nevertheless reveals and registers in his writing the conventional Elizabethan attitude toward Orientals. Contrary to Khulūsi's view of Othello, Hawamdeh, in "Shakespeare's Treatment of the Moor in Othello", tries to substantiate the focal point of his article that "Othello is a documentary expression of the Renaissance misconceptions, racial prejudices and stereotypical notions about Moors in particular and the Muslims in general." He goes on to say,

Shakespeare, like other Elizabethan playwrights, was clearly very much aware of the Western legacy of traditional misrepresentations, distortions, legends and popular images about Islam and Muslims. The Elizabethan inherited legacy vas established during long, yet incessant, centuries of military and at times intellectual, though polemical, confrontations between the Muslim Orient and Christian West. (Hawamdeh, Shakespeare's Treatment 93)

Also, in "Allusions to Muhammad in Shakespeare", Hawamdeh looks at a number of allusions to Muhammad, the Prophet of Islam, and how Shakespeare, to use Hawamdeh's own words,

demonstrates full awareness of, and reflects, the Renaissance traditional views of the Prophet of Islam, which portray him as a false deity, a devil, an imposter 
and a lecher, among other grotesque allegations. Throughout his canon, Shakespeare once refers [in Henry VI Part One, I.ii.140] to the Western popular legend of "Mahomet's dove", twice mentions "Mahu" [in King Lear, III.iv.140, and IV.i.63] as a name of a devil, twice uses the word "Mammat(s)" [in Romeo and Juliet, III.v.186 and Henry IV Part One, I.ii.90-92] to mean an idol (s), and employs the word "Termagant" in three forms [in 1 Henry IV, V.iv.114-115, Hamlet, II.ii.13, and in Antony and Cleopatra. (Hawamdeh, Allusions 54)

Hawamdeh reaches the conclusion that "Shakespeare clearly utilizes the Western perception of Islam as the religion of the sword, war and bloodshed" (Hawamdeh, Allusions 63). Not from such speculation as colours most of the comments given above, but from the evidence of the many plays in the canon, the fact remains that Shakespeare indeed knew a great deal of Arab characteristics and places, and probably admired them as many lines from his plays seem to suggest. Thus we find references to "Arabian trees" (in Othello, 5.2.350-1, and The Tempest, 3.3.22), to the "vasty wilds" and "perfumes" of Arabia (in The Merchant of Venice, 2.7.42, and Macbeth, 5.1.57), to the "Arabian birds" (in Antony and Cleopatra, 3.2.212, and Cymbeline, 1.6.1), or direct geographical references to Arabia, Syria, Antioch, Damascus, Aleppo, Tunis (in Coriolanus, Pericles, The Tempest, Henry VI, Macbeth, Othello) - to mention just of few of the best-known examples.

All these seem to indicate that the "East" in general occupied a special place in Shakespeare's heart, for which he expressed admiration in the memorable line, "I' th' East my pleasure lies", which he put in the mouth of Antony, the "Arabian bird" of Antony and Cleopatra. How, we may wonder, did Shakespeare come to know about such Arabian elements and places that are found in many of his plays, bearing in mind that these elements are hardly referred to in the major sources that Shakespeare had consulted? In an attempt to unravel this mystery, or part of it, a number of theories have been proposed by Arab critics and artists as well as by Western critics, the nature of which varies from stimulating remarks to somewhat strange and controversial speculations.

\section{From Arabization to appropriation}

One of the key tactics which the new generation of drama translators, particularly those who translated Shakespeare, deployed to establish their legitimacy in the field was their emphasis in their published translations on a purported fidelity to the original text. This was regardless of whether or not their actual translation practice honoured the ideal of 'fidelity' they promoted in the prefaces and short introductions to their translations. In three important translations published in 1912, one of Othello by Khalīl Mutran and two of 
Julius Caesar by Muhammad Hamdi and Sami al-Juraydini, the issue of fidelity was overemphasised in the translators' paratexts. Both Mutran and Hamdi state in the prefaces to their translations that theirs are almost literal renderings of what Shakespeare says, "letter for letter, word for word", where "no word, phrase, simile, metonymy, nor metaphor is left out".

The full title of Tanyus 'Abdu's second edition of his version of Hamlet (1902) reads: "The story of HAMLET, a play in five acts composed by Shakespeare the renowned English poet, Arabized by the skilled writer Tanyus Effendi 'Abdou, Owner of the well-reputed al-Sharq Newspaper". The keyword in this complex, meaningful title is "Arabized", and the question we are asking is: How far could Arabization go?

Almost one century after 'Abdu's stage versions, Arab contemporary playwrights are adapting and appropriating Shakespearean plays. Linda Hutcheon was very explicit about the direction that adaptation may take, when she asserts that adaptation, as a process of creation, "always involves both (re-)interpretation and then (re-)creation; this has been called both appropriation and salvaging, depending on your perspective (Hutcheon, 2013: 8, emphasis added).

Ali Ahmed Bakathir is remembered for his translation of Romeo and Juliet in blank verse in an attempt to demonstrate the richness and complexity of Arabic that allow for the translation of Shakespeare's plays in the original blank verse. Also, Bakathir adapted The Merchant of Venice in Shaylouk al-Jadid ("The New Shylock"), a play with a political message against Zionism and the state of Israel: "he adapts Shakespeare to set out his political stance vis-à-vis the Arab-Israeli conflict, drawing heavily on the stereotypical notions traditionally associated with Jews in English literature, especially Shakespeare's play" (Al-Shetawi, Arabic Adaptations 17).

The Syrian playwright Muhammad al-Maghut wrote Al-Muharej ("The Clown"), an adaptation of Othello, which conveys a fierce criticism of the corruption of politicians not only in Syria but also in the other Arab countries. According to Mahmoud Al-Shetawi, "The play serves two purposes: it incorporates Othello from a postcolonial perspective to suggest that Shakespeare, as a colonial dramatist, is consciously portraying Othello as foolish and violent to justify his defeat and eventual destruction" (Al-Shetawi Arabic Adaptations 20-21). The originality of Al-Muharej resides in the use of theatrical procedures and improvisation derived from the Italian commedia dell'arte; the performance is interactive, allowing the audience to suggest and change the theme of the play, in the tradition of the Arab masrah al-furjah. 


\section{Hamlet without Hamlet: Khazal Al-Majidi}

The Iraqi playwright Khazal al-Majidi considers that Shakespeare probes the depths of humanity, and his theatrical selections constitute a unique experience in re-reading the tragedies of the prominent English poet and writer and sheds light on the sunset of freedom in his country and the escalation of the lust for power and money. In the introduction to his theatrical anthology entitled "Shakespeare's Inferno" (2018), he writes:

If the Italian poet Dante wrote about Hell, Paradise and Purgatory in his legendary poetic epic "The Divine Comedy", Shakespeare also did it in most of his major tragedies descending and delving into the hell of life and the depths of humanity, not in the world of the afterlife as in Dante. Likewise, his comedies were a joyful delving to the paradise of life and inside it as well, and his historical plays were a kind of purgatory between this and that. (in Al-Janabi $\mathrm{np}$, my translation)

Al-Majidi presents his experience in re-reading and producing Shakespeare's tragedies to describe his hell, raging in him and in his country between the sunset of freedom in his country and the escalation of the lust for power and money that dominated him and is still present, and the fall of meteors of wars over it, which today has become the war of the entire Arab world. If Al-Majidi has dealt with these matters in his other plays, directly, in order to dig up the classes in his country and in his burning self, then, here, he offers us a unique experience in five plays in love with Shakespeare and distancing himself from him with new treatments, in form and content, and presenting unique texts of Arab theater.

To consider only one example, Shakespearean influences are the main contribution to Khazal al-Majidi's play Hamlit bila Hamlit ("Hamlet without Hamlet"). Although the text bears the name of the Shakespearean character, the writer treated this name in a way that differs from the original Hamlet, by drawing his own character and transcending all the constants and events through the exploitation of symbols and connotations, and conferring to Shakespeare's original text an implicit intertextuality. By a process of hybridization, Al-Majidi borrowed the characters' names from Shakespeare's play, and hybridized them. As a result, the characters changed and migrated from old classic to living reality.

The Iraqi playwright structures his play in seven acts, or scenes, to which he assigns explanatory titles, as follows: Scene I: Hamlet's Death (هوت هاملت ); Scene II: Ophelia's Confusion (حيرة أوفيليا); Scene III: Horatio's Escape (هروب هوراثيو): Scene IV: The Queen and Ophelia: The Woman and the Mirror (الملكة وأوفيليا: المراة و المرآة); Scene V: Gertrude’s Death (مصرع غرنرود); Scene VI: 
Laertes's Lusts (نهوات ليرتس); Scene VII: Flourish of Death (زهور الموت). There are seven characters: As for the script of the play, it consists of seven scenes and seven characters also present in the Shakespearean original: Claudius, Gertrude, Polonius, Laertes, Ophelia, Horatio, and the grave digger.

This hybridization aimed to strengthen the mythical dimension of the writer, especially in his play through the events summarized in King Hamlet's murder by his brother Claudius in complicity with Gertrude, his brother's wife. As a result, Hamlet, who is studying abroad, decides to return to Denmark to attend his father's funeral, but the ship sinks and he dies. Hamlet's death triggers his mother's feelings of grief despite the crime she had committed. In the midst of all these, Ophelia stands as a symbol of purity. Death has entered the ramparts of the city walls and its stench is felt everywhere. Confessions of the guilt that led to the ruin of the kingdom begin. Laertes, upon knowing that his ancestors are the true kings of Denmark, hence more deserving to inherit, kills the king and his son to become king himself. Later, he is killed by the grave digger.

According to Margaret Litvin, the play, first produced in 1992, "fits clearly into the post-1975 pattern". A more recent production of the play (2008), titled This is Baghdad, and directed by Monadhil Daood, emphasized "the violent imagery of Iraq's recent political history", incorporating stylistic elements of ta ziya theatre: "The use of this traditional Shi'a dramatic form, specific to passion plays commemorating the death of the Prophet Muhammad's grandsons Hassan and Husayn, carries a political charge: ta zìya was banned in Saddam Hussein's Iraq" (Litvin 185).

The play is about the struggle for power, which Al-Majidi borrowed from Hamlet as a general idea. As for the text, it is an independent text in itself that has nothing to do with Shakespeare's text, but he borrowed some dialogues for the real characters of Hamlet and worked to transform and transfer them to reality. Hence the anonymous, personal dialogue that Al-Majidi did not specify in the text in order to bring the recipient in a state of constant anticipation:

Ah ... yet this stiff, hardened body wears out to become dew. Oh my God ... to the extent that the customs of this world seem obsolete and outdated that ... please do not work without ... Damn this world ... Damn it. (al-Majidi, Hamlet bila Hamlet 468, my translation)]

Here, the lines show the hybridization process that took place between the Shakespearian text and the text of Al-Majidi. Its poetic formulation is an approach to Shakespeare's method in writing theatrical texts.

The theatrical text - the death of Hamlet in the first scene of the play - ends the true link between the Shakespearian text and the text of Al-Majidi, breaking the restrictions in the process of writing the theatrical text and departing from the norm in embodying those stories and representing them as 
mythical symbols to strengthen the events and draw the recipient's literary attention. The writer left the fixed taboos and broke the rigid traditions in a realistic manner. Hamlet without Hamlet is a mixture of literary genres that switch between the true spirituality of Hamlet and his own story, changing the centers of the main characters and transforming them into other characters, as the death of Ophelia was transferred to Hamlet in order to turn the scales and in order for the implicit message to surface. Here is one example:

Ophelia: Why did you leave me alone, Hamlet? Play to the rise of temptations and go into the pools of whims that our souls portray to us as conquests of horizons, breaking barriers and creating traps ... Our stomachs have entered the licking of the forbidden and our souls are saturated with abnormalities and abominations, and adorned with the corruption of the severity of the evil that is taking them to the abyss. (al-Majidi, Hamlet bila Hamlet 509, my translation)

Al-Majidi described, in his controlled way, the state of the society in which he lives and worked to transfer, via a realistic method, the historical discourse to become a speech stemming from the human conscience and aimed at the reformation of the Iraqi society. The speech is the result of a collective awareness of the human being in society and the work to purify the human soul from mistakes. It is the legend and what it carries in terms of latent powers, the strength of the text and the flexibility in moving through different times and places with the possibility of transforming characters and destinies, given that these destinies represent the whole society and that the product of hatred is hatred. It did not hit the center in Hamlet only, but also created other centers around which conflicts and doubts revolve, as the high language and short dialogues intensified the meanings and connotations with the fewest possible words through the use of lines as tools that work to create twinning and homogeneity in the context.

\section{Conclusions: Repositioning Shakespeare}

Probably Shakespeare is more appreciated by the average Arab reader or spectator than most other modem English or Western writers. If the latter present to him in a piece of literature strange philosophy and complicated contemporary Western themes and problems still alien to his culture and therefore quite hard to digest, Shakespeare, regardless of the complications of his language, has found a smooth path to his heart. In Shakespeare what chiefly matters to the Arab reader or playgoer is not the now archaic English in which he wrote his works, but the works themselves. In Shakespeare, the reader or the playgoer can encounter intimate issues and problems which he daily experiences. He is quick 
to respond particularly to the emotional and passionate elements inherent in many of Shakespeare's plays, should they be comedies or tragedies.

Of all Shakespeare's plays, Hamlet is perhaps the most often appropriated or interpolated into Arabic drama and literature. In numerous studies, American scholar Margaret Litvin has extensively explored the reception of Hamlet in Arabic drama, pointing out that Hamlet has been politically incorporated into Arab dramatic literature and theatre. In his article "Hamlet in Arabic" (2000), Mahmoud F. Al-Shetawi explored the various treatments of the play in Arabic literature, and Arabic drama in particular. For example Mamduh Udwan's play Hamlet Yastiqidu Muta'akhiran ("Hamlet Awakens Belatedly"), who rewrote Shakespeare's masterpiece in such a way as to express his concerns about political repression and corruption in his native Syria and in the Arab world at large. Udwan highlights the dilemma of the Arab intelligentsia with regard to the Arab-Israeli conflict, and comments on the decadence of Arab societies. The situation he creates in this political drama is reminiscent of the state of affairs in the Arab world shortly before the breakout of the 1967 War. By juxtaposing Hamlet's "rotten" world with the Arabic situation, Udwan tries to highlight the causes of defeat and comment on the malady which blights Arab intellectuals, especially their impotence to act positively towards their countries.

In December 2020, despite the unprecedented restrictions caused by the pandemic and the nation-wide economic unrest, a new play was staged in Baghdad, directed by Monadhil Daood, the Iraqi director who had previously adapted Al-Majidi's Hamlet Without Hamlet, produced Romeo and Juliet in Baghdad at the RSC (2012), and who had performed in Sulayman Al Bassam's Al-Hamlet Summit (2006, Polonius) and Richard III (2009, Catesby). The play was Forget Hamlet / Ophelia's Window, by the Iraqi theatre director and playwright Jawad al-Asadi. This is a rich, revolutionary text in which the Iraqi reality today is deeply blended with the reality of Shakespeare's time, more than four centuries ago. It is as if time were repeating itself, and redistributing the same roles over the days and years and making us follow suit against our will, to re-play the same roles in a different time and place, starting from the same pain and concern and to meet the same terrible appeal that groans betrayal, treachery, power and the power of the executioner.

All these add to our attempt at demonstrating how Shakespeare has been repositioned in the Arab world. Literary critics and scholars who have commented on postcolonial drama and the repositioning of Shakespeare in postcolonial studies have glossed over Arabic literary examples. Since Arabic rewrites of Shakespeare were not rendered in English, and have only recently been explored, postcolonial critics might be forgiven for this omission. Our purpose was to demonstrate that the appropriations of Shakespeare's dramas by 
Arabic literature discussed above illustrate the cultural impact of the West, Britain in this case, on Arabic drama and literature; and by studying these appropriations of Shakespeare in Arabic drama and literature in the context of the postcolonial literary theory, it fills a gap in comparative literary studies.

\section{WORKS CITED}

al-Azzam, Bakri. Certain Terms Relating to Islamic Observances: Their Meanings with Reference to Three Translations of the Qur'an and a Translation of Hadith. Diss. Durham University, 2005. http://etheses.dur.ac.uk/1775/

al-Janabi, Yousra. خزعل الماجدي يغوص في 'جحيم شكسبير' (khazaeal almajidiu yaghus fi 'jhim shaksabira' yasraa aljanabiu, Khazal Al Majidi dives into 'Shakespeare's Hell', خزعل-MEO_Middle East Online, 21.03.2020. https://middle-east-online.com الماجدي-يغوص-في-جحيم-شكسبير.

al-Juraydini, Sami. Riwayat Hamlet li-Shakespeare (The Play of Hamlet by Shakespeare). Cairo: al-Matba'a al-Rahmaniyya, 1922.

al-Majidi, Khazal. الأعمال المسرحية (Al'aemal almasrahiatu, Theatrical Works) Vol. 1. Beirut: almuasasat alearabiat lildirasat wa alnushri, 2011.

جحيم شكسبير (خمس مسرحيات تعيدإنتاج مسرح و سيرة شكسبير) . (jahim shaksubir: khms musrahayat teid'iintaj masrah w sirat shuksbir, Shakespeare's Inferno: five plays reproducing plays and Shakespeare's biography). Amann: Dar-Fadaat, 2018.

Al-Shetawi, Mahmoud F. "Arabic Adaptations of Shakespeare and Postcolonial Theory." Critical Survey 25.3 (2013): 4-28. JSTOR, http://www.jstor.org/stable/247 12406

—_. "Hamlet in Arabic." Hamlet Studies 22.1-2 (2000): 77-109.

Dickins, James, Sandor Hervey and Ian Higgins. Thinking Arabic Translation. London and New York: Routledge, 2002.

Hanna, Sameh F. "Decomercializing Shakespeare: Mutran's translation of Othello". In Shakespeare and the Arab World. Eds. Katherine Hennesey and Margaret Litvin. New York and Oxford: Berghahn, 2019. 35-62.

Hatim, Basil and Ian Mason. Discourse and the Translator. London: Longman, 1990.

Hawamdeh, Mufid. "Allusions to Muhammad in Shakespeare: a Lexico-Cultural Study", Damascus University Journal 13 (1988): 53-72.

"Shakespeare's Treatment of the Moor in Othello: an Oriental Perspective", International Journal of Islamic and Arabic Studies IV.1 (1987).

Haywood, John Alfred. Modern Arabic Literature (1800-1970): An Introduction, with Extracts in Translation. London: Lund Humphries, 1971.

Hutcheon, Linda. A Theory of Adaptation. London: Routledge, 2013.

'Iffat, Muhammad. Riwayat Makbith (The Play of Macbeth). Cairo: Matba'at alMuqattam, 1911.

Khulūsi, Safā'. "a1-'Anāsir a1-'Arabiyyah fi Adab Shaykisbir" ("The Arabic Elements in Shakespeare's Literature"). Ahl al-Naft, no. 59, June 1956. 
Litvin, Margaret. Hamlet's Arab Journey: Shakespeare's Prince and Nasser's Ghost. Princeton and Oxford: Princeton University Press, 2011.

Najm, Muhammad Yusif. Al-Masrahiyya fi al-Adab al-'Arabi al-Hadith: 1847-1914 (The Play in Modern Arabic Literature: 1847-1914). Beirut: Dar Beirut lil-Tiba'a wa al-Nashr, 1956.

Next Page Foundation. 2004. "Lost and Found in Translation. Translations' Support Policies in the Arab World". A study commissioned by the Next Page Foundation, conducted in 2004 by Thalassa Consulting and Gregor Meiering.

Scoville, Spencer Dan. The Agency of the Translator: Khalil Baydas' Literary Translations. Diss. University of Michigan, 2012. 